\title{
NUMERICAL MODEL OF SPHERICAL PARTICLE SALTATION IN A CHANNEL WITH A TRANSVERSELY TILTED ROUGH BED
}

\author{
NIKOLAY LUKERCHENKO, SIARHEI PIATSEVICH, ZDENEK CHARA, PAVEL VLASAK*
}

Institute of Hydrodynamics of Academy of Sciences of the Czech Republic, v. v. i., Pod Patankou 30/5, 16612 Prague 6, Czech Republic; *Corresponding author, mailto: vlasak@ih.cas.cz, phone: +420 233109019, fax: +420 233324361

This paper deals with the numerical simulation of spherical particle saltation in a channel with a rough transversely tilted bed. The numerical model presented is based on the 3D model of spherical particle saltation developed by the authors, which takes into account the translational and rotational particle motion. The stochastic method and the concept of a contact zone were used for the calculation of a particle trajectory and its dependence on the bed lateral slope, particle diameter, and shear velocity. The effect of the bed lateral slope results in a deviation of the particle trajectory from the downstream direction. Some examples of the calculation are presented. The trajectories of the saltating particles starting their movements from one point were calculated and it was shown that they are of random character and together create a bundle or fascicle of trajectories. It was found that the centrelines of the bundles can be approximated by the straight lines for low and moderate values of the bed transverse slope, i.e. slopes less than $20^{\circ}$. The angle of deviation of the centreline from the downstream direction increases when the bed lateral slope and/or the particle diameters increase. However, with increasing shear velocity, the deviation angle decreases. Due to the lateral bed slope the particles are sorted according to their size, and the criteria for sorting particles were defined. An example of the particle sorting was calculated and the separable and nonseparable regions were determined.

KEY WORDS: Saltation, Transversely Tilted Bed, Particle-Bed Collision, Particle Sorting.

Nikolaj Lukerchenko, Siarhei Piatsevich, Zdeněk Chára, Pavel Vlasák: NUMERICKÝ MODEL SALTACE KULOVITÉ ČÁSTICE V KORYTĚ S PŘIĆČNĚ SKLONĚNÝM DRSNÝM DNEM. J. Hydrol. Hydromech., 57, 2009, 3; 16 lit., 5 obr.

Studie popisuje numerickou simulaci saltačního pohybu kulovité částice $\mathrm{v}$ korytě s prríčně skloněným drsným dnem. Předložený numerický model je založen na autory vyvinutém 3D modelu saltačního pohybu kulovité částice, který počitá $\mathrm{s}$ translačním i rotačním pohybem částice. Pro výpočet trajektorie částice a její závislosti na příčném sklonu dna koryta, průměru částice a smykové rychlosti nosné kapaliny byla použita stochastická metoda a koncept kontaktní zóny. Vlivem př́čného sklonu dna koryta dochází k odchylce trajektorie částice od směru proudu. Trajektorie částic začínajících svůj pohyb v jednom bodě byly vypočteny a bylo ukázáno, že trajektorie jsou náhodného charakteru a tvoří společně svazek trajektorií, jehož osa může být pro nízké a střední hodnoty př́íného sklonu dna koryta aproximována př́ímkou. Vlivem příčného sklonu dna koryta může dojít $\mathrm{k}$ roztrrídění částic podle velikosti. Bylo spočteno několik príkladů trrídění, definováno kriterium tř̌́dění a určeny oblasti třídění podle velikosti částic a sklonu dna koryta.

KLÍČOVÁ SLOVA: saltace, příčně skloněné dno, kolise částice-dno, trrídění částic.

\section{Introduction}

The modelling of the saltation process in the case of a transversely tilted bed is important for the understanding of natural phenomena such as bank erosion, river bed topography, sediment sorting, and stream braiding (Sekine and Parker, 1992). According to Talmon et al. (1995), in this case "correct modelling is very important because it, for instance, affect transverse bed slopes in bends and the wave length and damping of spatial river-bed deformations".

Most of the numerical models of saltation particle movement are 2D (e.g. Wiberg and Smith, 1985; Nino and Garcia, 1994; Lee et al., 2000; Lukerchenko et al., 2006). However, a description of the saltation process in the case of a transversely tilted bed can be realised properly only if the 3D pattern 
of particle saltation is used (Lukerchenko et al., 2009).

Sekine and Kikkawa (1992) and Lee et al. (2006) developed 3D saltation models which were deterministic for the particle motion in fluid but stochastic for the particle-bed collision stage. Neither model took into account the particle rotation and both assumed a spherical shape and uniform size of the saltating particles and a bed formed by equal particles.

As a result of the particle-bed collisions, the particle gains angular velocity, which can reach a few tens of revolutions per second (Nino and Garcia, 1998). Therefore, to describe the saltation process reliably the model of saltation must take into account not only the translational but also the rotational particle motion. The present paper uses as a basis the 3D numerical model of spherical particle saltation (Lukerchenko et al., 2003, 2004, 2009), in which the particle rotation is taken into account and the problem of a particle-bed collision is solved using the concept of a contact zone.

The model allows the calculation of the particle trajectory and expression of the bed lateral slope and other parameters of the effect of the saltation process on the lateral deviation of the particle trajectory.

\section{The mathematical model of the saltation}

The principal assumptions of the model are as follows. The saltating particle is spherical and its translational and rotational movements are taken into account. The effect of turbulence fluctuations on a saltating particle is neglected. The concentration of the conveyed particles is sufficiently low to neglect mutual collisions between moving particles and the influence of the particles on fluid flow. Therefore the motion of a set of particles can be represented by the motion of a single particle. The effects of the drag force, submerged gravitational force, Basset history force, force due to added mass, Magnus force, and drag moment acting on the particle are taken into account in the model.

Let us define the channel bed as a plane spaced over the top of the bed's roughness. The fluid flow is steady and uniform, and the velocity profile can be described by the logarithmic law. The bed level is inclined to the horizontal plane in the downstream direction and also in the lateral direction. The longitudinal and lateral slopes can be defined as follows. The coordinate axis $O y^{\prime \prime}$ is vertical and the coordinate axis $O x^{\prime \prime}$ is horizontal in the down- stream direction, that is, in the direction of the fluid velocity vector. The angle $\theta_{s}$ is the angle of the channel bed slope in the downstream direction and the angle $\theta_{l}$ is the angle of the channel bed slope in the lateral direction (see Fig. 1).

The coordinate plane $O x z$ associated with the bed level can be obtained from the coordinate's plane $O x^{\prime \prime} z^{\prime \prime}$ using two transformations of the coordinate system. The first is the rotation of the coordinate system $O x^{\prime \prime} y^{\prime \prime} z^{\prime \prime}$ by the angle $\theta_{s}$ around the axis $O z^{\prime \prime}$ (see Fig. 1). The new coordinate system is $O x^{\prime} y^{\prime} z^{\prime}$. The second transformation is the rotation of the coordinate system $O x^{\prime} y^{\prime} z^{\prime}$ by the angle $\theta_{l}$ around the coordinate axis $O x^{\prime}$. The system of equations governing particle motion is written in the resulting coordinate system, Oxyz. The gravitational acceleration vector in the coordinate system Oxyz can be written as

$\mathbf{g}=\left(\mathrm{g} \cos \theta_{s},-\mathrm{g} \cos \theta_{s} \cos \theta_{l}, \mathrm{~g} \cos \theta_{s} \sin \theta_{l}\right)$.

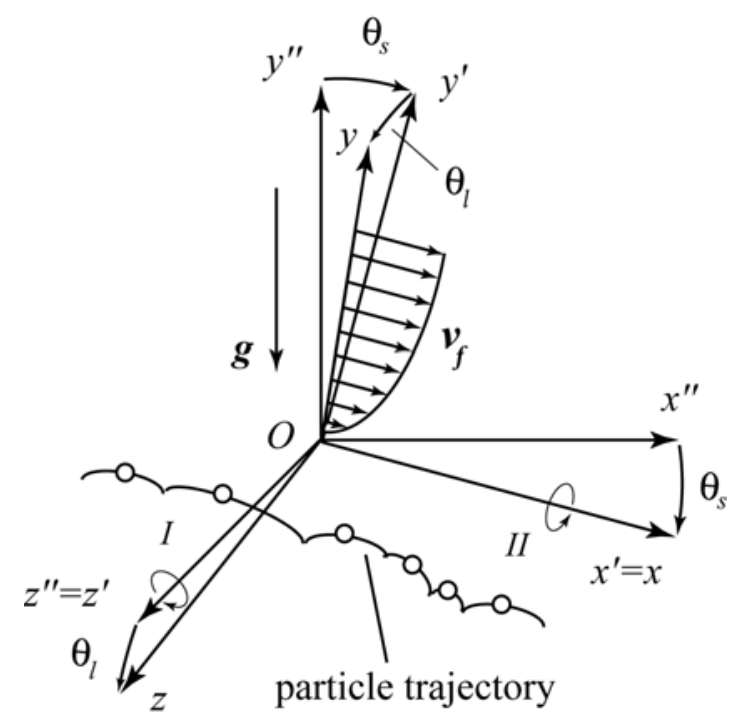

Fig. 1. Definition of the angle of the bed slope to the horizontal plane.

Obr. 1. Definice úhlů sklonu dna koryta $\mathrm{k}$ vodorovné rovině (particle trajectory - trajektorie částice).

Let us consider a spherical homogeneous particle of diameter $d_{p}$ and density $\rho_{p}$ moving in a fluid of density $\rho$ and dynamic viscosity $\mu$. The system of governing equations for the particle saltation motion can be written as

$\frac{d \boldsymbol{r}_{O p}}{d t}=\boldsymbol{v}$

$\rho_{p} \frac{d \boldsymbol{v}}{d t}=\boldsymbol{F}_{D}+\boldsymbol{F}_{m}+\boldsymbol{F}_{\mathrm{g}}+\boldsymbol{F}_{B}+\boldsymbol{F}_{M}$ 
$J \frac{d \omega}{d t}=\boldsymbol{M}$,

where $t$ is the time, $\boldsymbol{r}_{O p}\left(x_{p}, y_{p}, z_{p}\right)-$ the radius-vector of the particle centre of mass, $\boldsymbol{v}\left(v_{x}, v_{y}, v_{z}\right)$ - the vector of the velocity of the particle centre of mass, $\boldsymbol{\omega}\left(\omega_{x}, \omega_{y}, \omega_{z}\right)$ - the vector of angular velocity of the particle rotation about its centre of mass, $J$ - the particle moment of inertia, $\boldsymbol{F}_{D}, \boldsymbol{F}_{m}, \boldsymbol{F}_{\mathrm{g}}, \boldsymbol{F}_{B}$, and $\boldsymbol{F}_{M}$ are the drag force, force due to added mass, submerged gravitational force, Basset history force, and Magnus force per unit volume, respectively, and $\boldsymbol{M}$ is the drag torque of viscous forces acting on the particle.

The particle motion is determined by two dimensionless parameters: the translational Reynolds number (or Reynolds number) $\operatorname{Re}=\left|\boldsymbol{v}_{R}\right| d_{p} \rho / \mu$ and the rotational Reynolds number $\operatorname{Re}_{\omega}=\left|\omega_{R}\right| r_{p}^{2} \rho / \mu$, where $\boldsymbol{v}_{R}=\boldsymbol{v}-\boldsymbol{v}_{f}$ is the vector of particle-fluid relative velocity, $\boldsymbol{v}_{f}\left(v_{f x}, \boldsymbol{v}_{f y}, \boldsymbol{v}_{f z}\right)$ - the vector of fluid velocity, $\boldsymbol{\omega}_{R}=\boldsymbol{\omega}-0.5$ rot $\boldsymbol{v}_{f}-$ the particle relative angular velocity, and $r_{p}=0.5 d_{p}$ is the particle radius.

The flow velocity distribution can be described by the logarithmic law

$v_{f x}(y)=\frac{u_{*}}{k} \ln \left(\frac{y}{y_{0}}\right), v_{f y}=v_{f z}=0$,

where $k=0.4-$ the Karman constant; $y_{0}=$ $=0.11(\mu / \rho u *)+0.033 k_{s}$ (Nikuradze, 1933), $u_{*}-$ the fluid shear velocity, and $k_{s}$ - the bed roughness.

From Nino and Garcia (1994) the drag force term can be written as

$\boldsymbol{F}_{D}=-0.75 C_{D} \rho\left|\boldsymbol{v}_{R}\right| \boldsymbol{v}_{R} / d_{p}$,

where dimensionless drag force coefficient $C_{D}$ of a rotating spherical particle moving in fluid can be calculated from the equation (Lukerchenko et al., 2008):

$C_{D}=C_{D 0}\left(1+0.065 \cdot \mathrm{Re}_{\omega}^{0.3}\right)$,

where

$$
\begin{aligned}
& C_{D 0}=\frac{24}{\mathrm{Re}}\left(1+0.15(\mathrm{Re})^{\frac{1}{2}}+\right. \\
& +0.017 \mathrm{Re})-\frac{0.208}{1+10^{4} \mathrm{Re}^{-0.5}},
\end{aligned}
$$

is the drag force coefficient of a particle moving in fluid without rotation (Nino and Garcia, 1994).
Eq. (8) is valid for the Reynolds number range relevant to the saltation mode of sediment transport.

For the 3D case, the expression for the force due to added mass can be written as

$\boldsymbol{F}_{m}=\rho C_{m}\left[(\boldsymbol{v} \nabla) \boldsymbol{v}_{f}-\frac{d \boldsymbol{v}}{d t}\right]$,

where $C_{m}=1 / 2$ is the added mass coefficient.

The submerged gravitational force is the difference between the gravitational force and the Archimedean force

$\boldsymbol{F}_{\mathrm{g}}=\left(\rho_{p}-\rho\right) \mathbf{g}$.

The Basset history force is

$\boldsymbol{F}_{B}=-\frac{9}{d_{p}} \sqrt{\frac{\mu \rho}{\pi}} \int_{0}^{t} \frac{d \boldsymbol{v}_{R}}{d \tau} \frac{d \tau}{\sqrt{t-\tau}}$.

The translational movement of the solid sphere with simultaneous rotation in the viscous fluid induced the lateral force known as the Magnus force:

$$
\boldsymbol{F}_{M}=C_{M} \rho\left(\boldsymbol{\omega}_{R} \times \boldsymbol{v}_{R}\right),
$$

where $C_{M}$ is the dimensionless Magnus force coefficient (Oesterle and Dinh, 1998):

$$
\begin{aligned}
& C_{M}=0.0844 \frac{\mathrm{Re}}{\operatorname{Re}_{\omega}}+ \\
& +\left(0.75-0.0844 \frac{\operatorname{Re}}{\operatorname{Re}_{\omega}}\right) \exp \left(-0.1 \operatorname{Re}^{0.3} \operatorname{Re}_{\omega}^{0.4}\right)
\end{aligned}
$$

The drag moment can be written as

$$
\boldsymbol{M}=-C_{\omega} \frac{\rho}{2} \boldsymbol{\omega}_{R}\left|\boldsymbol{\omega}_{R}\right| r_{p}^{5},
$$

where $C_{\omega}$ is the dimensionless drag rotation coefficient of the rotating particle moving in fluid, which can be calculated according to Lukerchenko et al. (2008) as

$C_{\omega}=C_{\omega 0}(1+0.0044 \sqrt{\mathrm{Re}})$,

where $C_{\omega 0}$ is the dimensionless drag rotation coefficient given by the experimental investigation by Sawatzki (1970) for the rotating sphere in calm water.

The system of equations describing the particle motion in the channel is solved numerically using a fourth-order Runge-Kutta scheme (Lukerchenko et al., 2004). The numerical model of the particle-bed collision is described in detail by Lukerchenko et al. (2004). 


\section{Result of the calculations}

The effect of the transversely tilted bed on the particle saltation mainly results in the lateral deviation of the particles' trajectories from the downstream direction in agreement with the lateral slope of the channel bed. For the purpose of particle movement simulation, the fluid density, $\rho=10^{3} \mathrm{~kg}$ $\mathrm{m}^{-3}$, and the fluid dynamic viscosity, $\mu=10^{-3} \mathrm{~Pa} \mathrm{~s}^{-1}$ (both corresponding to water), the particle density, $\rho_{p}=2650 \mathrm{~kg} \mathrm{~m}^{-3}$ (corresponding to sand), and the gravitational acceleration, $\mathrm{g}=9.81 \mathrm{~m} \mathrm{~s}^{-2}$, were used.

\subsection{The bundle of saltating particle trajectories}

The particle trajectory has a random character and thus the bundle or fascicles of the particles' trajectories, which start from a point named the bundle origin, were studied. Some examples of the bundle of saltating particle trajectories projected onto the coordinate plane $O x z$ are shown in Fig. 2 for the case of the channel bed without the lateral slope (i.e. for $\theta_{l}=0$ ) and for the cases of the channel bed with the lateral slope, that is, for $\theta_{l}$ is equal to 5 and 10 degrees.

Let us consider the bundle of particle trajectories $z_{i}=z_{i}(x)$ in the projection onto the coordinate plane Oxz. The bundle axis is the line $z_{a}=z_{a}(x)$, where $z_{a}$ $(x)$ is the average value of the coordinates $z_{i}$ of all bundle trajectories for the same coordinate $x$. In this case the bundle boundary is the pair of lines $z_{b}=z_{a}$ $(x) \pm \sigma_{z}(x)$, where $\sigma_{z}(x)$ is the standard deviation of the coordinates $z_{i}(x)$ of the particle trajectories from the average value $z_{a}(x)$ for the same coordinate $x$. The calculations showed that the bundle axis can be approximated by a nearly straight line and, similarly, the bundle boundaries can be approximated by straight lines. Let us also define a bundle region as the region between the bundle boundaries.

The deviation angle $\alpha_{p}$ is the angle between the bundle axis and the downstream direction, and the disperse angle $\Delta \alpha_{p}$ is the angle between the bundle boundary and the bundle axis. The bundle boundary is determined by the standard deviation of the particle trajectories from the bundle axis.

Both $\alpha_{p}$ and $\Delta \alpha_{p}$ are functions of the saltation parameters

$\alpha_{p}=\alpha_{p}\left(\theta_{l}, d_{p}, u_{*}, k_{s}, \rho_{p}, \rho, \mu, \mathrm{g}\right)$,

and

$\Delta \alpha_{p}=\alpha_{p}\left(\theta_{l}, d_{p}, u_{*}, k_{s}, \rho_{p}, \rho, \mu, \mathrm{g}\right)$.
The effects of the shear velocity $u_{*}$, the particle diameter $d_{p}$, and the channel bed lateral slope $\theta_{l}$ are shown in Fig. 3 for three values of the shear velocity and three different particle diameters. The value of the deviation angle $\alpha_{p}$ increases when the value of the bed lateral slope $\theta_{l}$ increases. In the studied range of $\theta_{l}$, that is from zero to 20 degrees, the dependence is close to linear. With increases in shear velocity, the deviation angle decreases, while in contrast the deviation angle increases with increases in particle diameter.

\subsection{Particle sorting}

The effect of the particle diameter $d_{p}$ on the deviation angle $\alpha_{p}$ is shown in Fig. 4 for the lateral slope of the channel bed $\theta_{l}=20^{\circ}$ and the bed roughness $k_{s}=1 \mathrm{~mm}$. The dependence of the deviation angle on particle size is a monotonously increasing function; it suggests the possibility of the selection of particles according to the diameter of the particle in a channel with a laterally sloped bed. This process can be called particle sorting. However, particle sorting is a relatively complex process which depends not only on the particle diameter but also on the lateral slope of the channel bed, liquid velocity, bed roughness, and other parameters.

However, if the particle diameter varies from 0.5 $\mathrm{mm}$ to $5 \mathrm{~mm}$, the deviation angle changes only slightly, in the range of a few degrees. Hence the problem of particle sorting due to the transversely tilted bed is connected to the question: Particles of what diameters can be sorted in this way? The answer is not simple and requires special investigation of the particle sorting criteria.

Let us consider two bundles of particle trajectories of the same origin. The particles have different diameters, $d_{p 0}$ and $d_{p}$, while all other parameters of the particles and channel, that is, their density $\rho_{\mathrm{p}}$, shear velocity $u_{*}$, bed roughness $k_{s}$, and lateral slope $\theta_{l}$, are the same. It is reasonable to suppose that the particles will be separated if their bundle regions do not intersect, that is, do not have common points except the common origin. This condition can be written as

$\left(\alpha_{p 0}+\Delta \alpha_{p 0}<\alpha_{p}-\Delta \alpha_{p}\right) \vee\left(\alpha_{p 0}-\Delta \alpha_{p 0}<\alpha_{p}+\Delta \alpha_{p}\right)$.

Condition (18) is the first approximation and can be called the criterion for the rough rate of sorting, because about $32 \%$ of the particle trajectories of the given bundle can exceed the bundle boundary. The criteria for the middle, fine, and very fine rates 

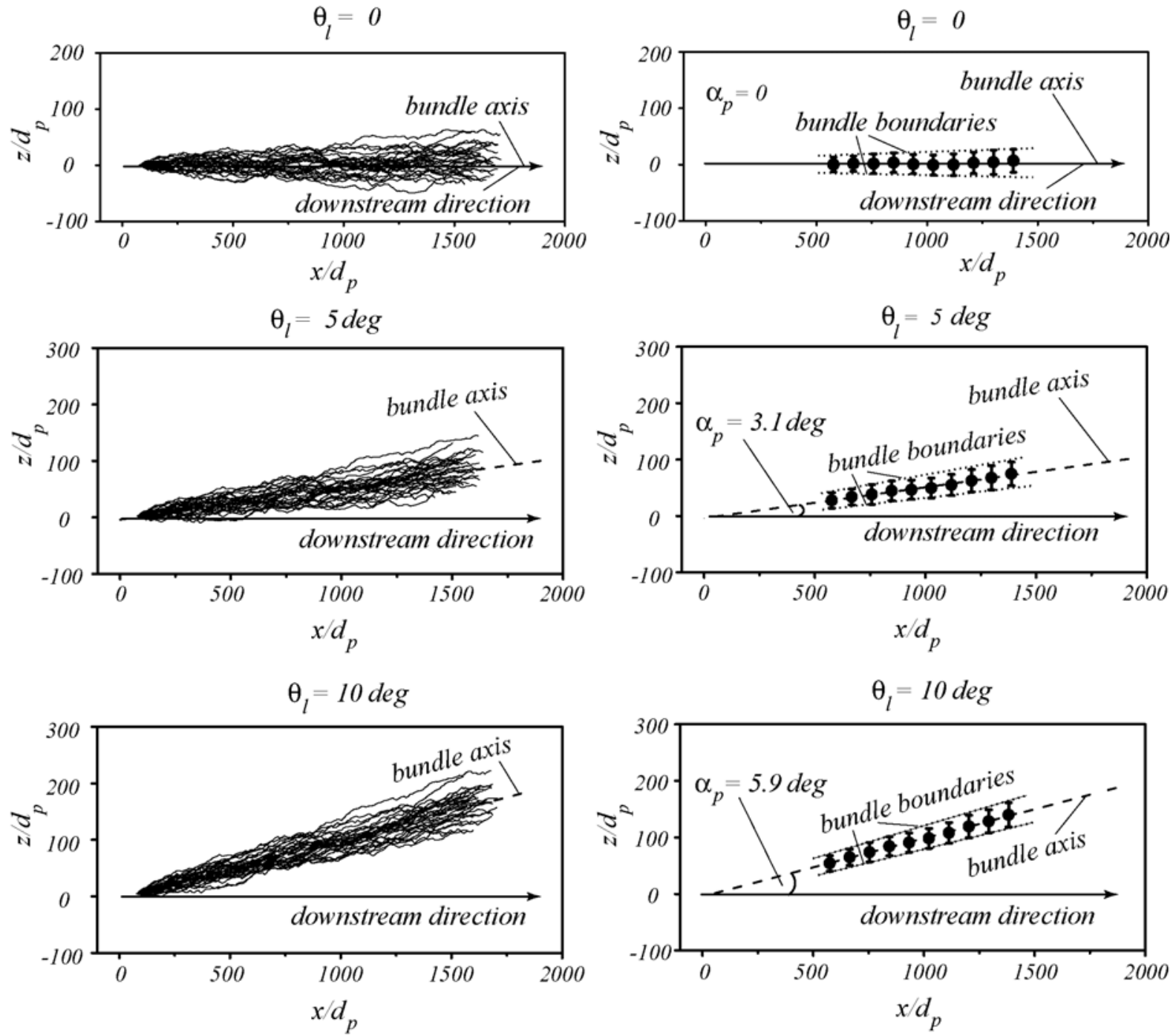

Fig. 2. The bundles of saltating particle trajectories for different values of the bed level lateral slope $\theta_{l}\left(d_{p}=1 \mathrm{~mm}, \rho_{p} / \rho=2.65, k_{s}=\right.$ $=1 \mathrm{~mm}, u_{*}=0.025 \mathrm{~m} \mathrm{~s}^{-1}$ ).

Obr. 2. Svazky trajektorií částic pohybujících se saltací pro různé př́icné sklony dna koryta $\theta_{l}\left(d_{p}=1 \mathrm{~mm}, \rho_{p} / \rho=2,65, k_{s}=1 \mathrm{~mm}\right.$, $u_{*}=0,025 \mathrm{~m} \mathrm{~s}^{-1}$; bundle axis - osa svazku trajektorií, bundle boundaries - hranice svazku trajektorií , downstream direction - směr proudu).
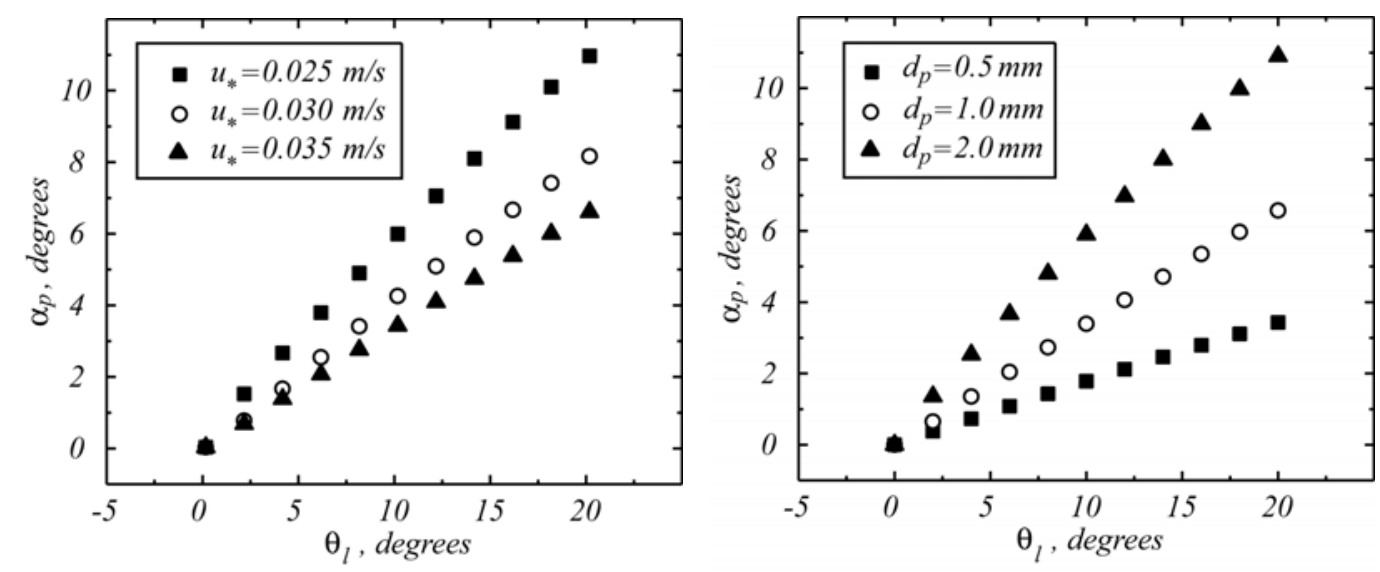

Fig. 3. The deviation angle $\alpha_{p}$ versus the lateral slope of the channel bed $\theta_{l}$.

Obr. 3. Závislost deviačního úhlu $\alpha_{p}$ na př́čném sklonu dna koryta $\theta_{l}$. 
of sorting can be determined in a similar way, and hence the bundle boundaries can be defined as 2 , 2.6, and 3 standard deviations of the particle trajectories from the bundle axis, respectively. In these cases, only about $5 \%, 1 \%$, and $0.3 \%$ of the particle trajectories of the given bundle can exceed the bundle boundary, respectively. Furthermore, the rough sorting criterion is used.

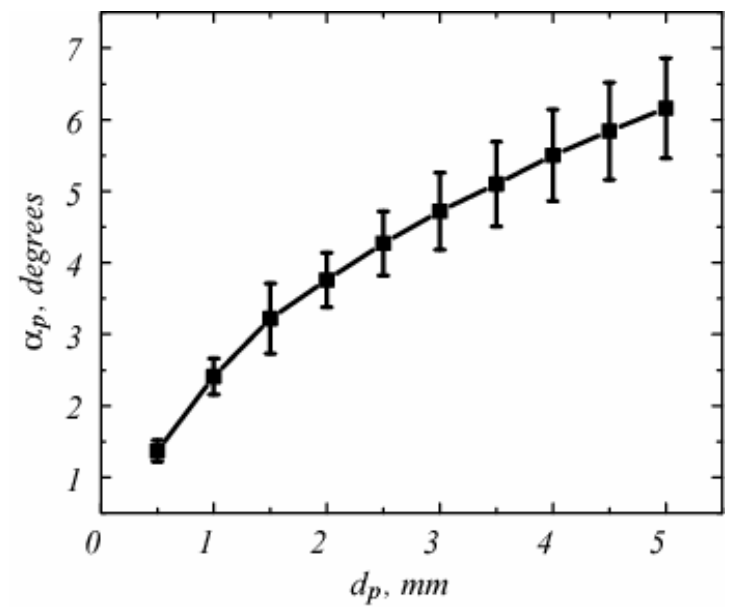

Fig. 4. The deviation angle $\alpha_{p}$ of the bundle axis from the downstream direction versus the particle diameter $d_{p}\left(\theta_{l}=20^{\circ}\right.$, $\rho_{p} / \rho=2.65, k_{s}=1 \mathrm{~mm}, u_{*}=0.07 \mathrm{~m} \mathrm{~s}^{-1}$ ).

Obr. 4. Závislost deviačního úhlu $\alpha_{p}$ osy svazku na průměru částice $d_{p}\left(\theta_{l}=20^{0}, \rho_{p} / \rho=2.65, k_{s}=1 \mathrm{~mm}, u_{*}=0.07 \mathrm{~m} \mathrm{~s}^{-1}\right)$.

The calculated results of sorting the particles with diameter $d_{p 0}=1 \mathrm{~mm}$ and the particles with diameters varying from $0.2 \mathrm{~mm}$ to $4 \mathrm{~mm}$ are shown in Fig. 5. The dotted line is the boundary of the separation, which indicates the minimal value of the channel bed lateral slope $\theta_{l}$ for which the separation of particles with the given diameter $d_{p}$ and diameter $d_{p 0}=1 \mathrm{~mm}$ is realised. Above this value of the lateral slope the separation occurs and below this value the separation does not occur. The higher the value of the channel bed lateral slope $\theta_{l}$, the more efficient the particle separation.

\section{Conclusions}

A 3D numerical model of spherical particle saltation in a channel with a transversely tilted rough bed was developed. The model takes into account the translational and rotational movement of the particle and the particle-bed collisions. During the saltation, the drag force, submerged gravitational force, Basset history force, force due to added mass, Magnus force, and drag moment act on the particle.

The effect of the transversely tilted channel bed mainly results in the lateral deviation of the particle trajectories from the downstream direction; the deviation is in agreement with the lateral slope of the channel bed.

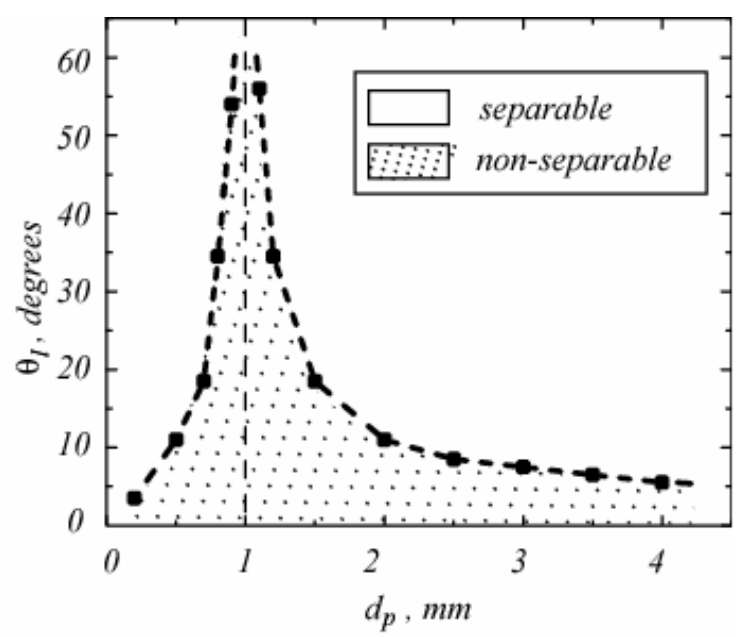

Fig. 5. The separable and non-separable regions $\left(d_{p 0}=1 \mathrm{~mm}, k_{s}\right.$ $\left.=1 \mathrm{~mm}, \rho_{p} / \rho=2.65, u *=0.058 \mathrm{~m} \mathrm{~s}^{-1}\right)$.

Obr. 5. Zóny separace a neseparace $\left(d_{p 0}=1 \mathrm{~mm}, k_{s}=1 \mathrm{~mm}\right.$, $\left.\rho_{p} / \rho=2,65, u_{*}=0,058 \mathrm{~m} \mathrm{~s}^{-1}\right)$.

Trajectories of particles starting their movements from one point are of a random character and together create a bundle or fascicle of trajectories. Definitions of the bundle origin, bundle axis, bundle boundaries, and bundle region were introduced. Based on the particle trajectory simulation it was found that the bundle axis and the bundle boundaries can be approximated by straight lines. The angle of deviation $\alpha_{p}$ of the bundle axis from the downstream direction is nearly linearly dependent on the lateral channel bed slope $\theta_{l}$, varying between zero and 20 degrees. The deviation angle $\alpha_{p}$ increases when the channel bed lateral slope $\theta_{l}$ or particle diameter $d_{p}$ increases and the shear velocity $u *$ decreases.

The possibility of particle sorting according to particle size occurring during their saltation movement in a channel with a transversely tilted rough bed was studied and the criteria for particle separation were defined. The separable and non-separable regions depending on the values of the particle diameter and the channel bed lateral slope were determined. 
Acknowledgements. The authors gratefully acknowledge the support of the Grant Agency of the Czech Republic, through project no. GA103/06/1487, and the Academy of Sciences of the Czech Republic, through Institutional Research Plan AV0Z20600510.

List of symbols

$\begin{array}{ll}C_{D} & - \text { drag force coefficient }[-], \\ C_{D 0} & - \text { drag force coefficient in the case } \omega_{R}=0[-], \\ C_{m} & \text { - force due to added mass coefficient }[-], \\ C_{M} & - \text { Magnus force coefficient }[-],\end{array}$

$C_{\omega} \quad-$ drag rotation coefficient $[-]$,

$C_{\omega 0} \quad-$ drag rotation coefficient in the case $\boldsymbol{v}_{\boldsymbol{R}}=0[-]$,

$d_{p} \quad-$ diameter of the moving particle [m ],

$\boldsymbol{F}_{B} \quad-$ Basset history force per unit volume $\left[\mathrm{N} \mathrm{m}^{-3}\right]$,

$\boldsymbol{F}_{D} \quad-$ drag force per unit volume $\left[\mathrm{N} \mathrm{m}^{-3}\right]$,

$\boldsymbol{F}_{\mathrm{g}} \quad-$ submerged gravitational force per unit volume $\left[\mathrm{N} \mathrm{m}^{-3}\right]$,

$\boldsymbol{F}_{m} \quad-$ force due to added mass per unit volume $[\mathrm{N}$ $\left.\mathrm{m}^{-3}\right]$,

$\boldsymbol{F}_{M} \quad-$ Magnus force per unit volume $\left[\mathrm{N} \mathrm{m}^{-3}\right]$,

g - vector of gravitational acceleration $\left[\mathrm{m} \mathrm{s}^{-2}\right]$,

$J \quad-$ particle moment of inertia $\left[\mathrm{kg} \mathrm{m}^{2}\right]$,

$k-$ Karman constant [-],

$k_{s} \quad-$ bed roughness [m],

$\boldsymbol{M} \quad-$ drag moment of viscous forces acting on a rotating particle in fluid $[\mathrm{N} \mathrm{m}]$,

$r_{p} \quad-$ radius of the moving particle [m],

$\boldsymbol{r}_{O p}\left(x_{p}, y_{p}, z_{p}\right)$ - radius-vector of the particle centre of mass $[\mathrm{m}]$,

Re $\quad-$ translational Reynolds number [-],

$\operatorname{Re}_{\omega} \quad-$ rotational Reynolds number [-],

$t \quad-$ time [s],

$u_{*} \quad-$ fluid shear velocity $\left[\mathrm{m} \mathrm{s}^{-1}\right]$,

$\boldsymbol{v}_{f}\left(v_{f x}, \boldsymbol{v}_{f y}, \boldsymbol{v}_{f z}\right)$ - vector of the fluid velocity $\left[\mathrm{m} \mathrm{s}^{-1}\right]$,

$\boldsymbol{v}\left(v_{x}, v_{y}, v_{z}\right)$ - vector of velocity of the particle centre of mass $\left[\mathrm{m} \mathrm{s}^{-1}\right]$,

$v_{\boldsymbol{R}} \quad-$ vector of the particle relative velocity $\left[\mathrm{m} \mathrm{s}^{-1}\right]$,

$y_{0} \quad-$ elevation of zero fluid velocity [m ],

$\alpha_{p} \quad-$ deviation angle - angle of the bundle axis deviation from the downstream direction, [degrees],

$\Delta \alpha_{p} \quad$ - disperse angle - angle between the bundle boundary and the bundle axis [degrees],

$\mu \quad-$ dynamic viscosity [Pa s],

$\theta_{l} \quad-$ angle of the bed level lateral slope [degrees],

$\theta_{s} \quad-$ angle of the bed level downstream slope [degrees],

$\rho \quad-$ fluid density $\left[\mathrm{kg} \mathrm{m}^{-3}\right]$,

$\rho_{p} \quad-$ density of the moving particle $\left[\mathrm{kg} \mathrm{m}^{-3}\right]$,

$\boldsymbol{\omega}\left(\omega_{x}, \omega_{y}, \omega_{z}\right)$ - vector of angular velocity of the particle rotation about its centre of mass $\left[\mathrm{s}^{-1}\right]$,

$\omega_{R}$

\section{REFERENCES}

LEE H.Y., CHEN Y.H., YOU J.Y., LIN Y.T., 2000: Investigation of continuous bed load saltating process. J. Hydraul. Eng., ASCE, 126, 9, pp. 691-700.

LEE H.Y., LIN Y.T., CHEN Y.H., YOU J.Y. WANG H.W., 2006: On three-dimensional continuous saltating process of sediment particles near the channel bed. J. Hydraulic Research, 44, 3, pp. 374-389.

LUKERCHENKO N., CHARA Z., VLASAK P., 2003: 3D Mathematical model of spherical particle saltatory movement in open channel with rough bed. Proc. Engineering Mechanics 2003, Svratka (Czech Republic), 12-15 May 2003, (CD ROM, 7 pages).

LUKERCHENKO N., CHARA Z., VLASAK P., 2004: 3D Numerical model of particle-bed collision in particle-laden flow in channel with rough bed. Proc. $12^{\text {th }}$ Int. Conf. on Transport \& Sedimentation of Solid Particles, Prague (Czech Republic), 20-24 September 2004, pp. 493-499.

LUKERCHENKO N., CHARA Z., VLASAK P., 2006: 2D Numerical model of particle-bed collision in fluid-particle flows over bed. J. Hydraul. Res., 44, 1, pp. 70-78.

LUKERCHENKO N., KVURT YU., KHARLAMOV A., CHARA Z., VLASAK P., 2008: Experimental evaluation of the drag force and drag torque acting on a rotating spherical particle moving in fluid. J. Hydrol. Hydromech., 56, 2, pp. 88-94.

LUKERCHENKO, N., PIATSEVICH, S., CHARA, Z., VLASAK, P., 2009: 3D Numerical model of the spherical particle saltation in a channel with a rough fixed bed. J. Hydrol. Hydromech., 57, 2009, 2, pp. 100-112.

NIKURADZE, J., 1933: Strömungsgesetze in rauben rohren. Ver. Deut. Ing. Forsch.

NINO Y. and GARCIA M., 1994: Gravel saltation. 2. Modeling. Water Resour. Res., 30, 6, pp. 1915-1924.

NINO, Y., GARCIA, M., 1998: Experiments on saltation of sand in water. J. Hydraul. Eng., ASCE, 124, pp. 1014-1025.

OESTERLE B., DINH BUI T., 1998: Experiments on the lift of a spinning sphere in the range of intermediate Reynolds numbers. Exp. Fluids., 25, pp. 16-22.

SAWATZKI O., 1970: Das Stromungsfeld um eine rotierende Kugel. Acta Mechanica, 9, pp. 159-214.

SEKINE M., PARKER G., 1992: Bed-load transport on transverse slope. I. J. Hydraul. Eng., 118, 4, pp. 513-535.

SEKINE M., KIKKAWA H., 1992: Mechanism of saltating grains. II. J. Hydraul. Eng., 118, 4, pp. 536-558.

TALMON A.M., VAN MIERLO M.C.L.M., STRUIKSMA N., 1995: Laboratory measurements of the direction of sediment transport on transverse alluvial-bed slopes. J. Hydraul. Res., 33, 4, pp. 495-517.

WIBERG P.L., SMITH J.D., 1985: A theoretical model for saltating grains in water. J. Geophys. Res., 90, (C4), pp. 7341-7354.

Received 15. October 2008 Scientific paper accepted 19. February 2009 
NUMERICKÝ MODEL SALTACE KULOVITÉ ČÁSTICE V KORYTĚ S PŘICČNĚ SKLONĚNÝM DRSNÝM DNEM

\author{
Nikolaj Lukerchenko, Siarhei Piatsevich, \\ Zdeněk Chára, Pavel Vlasák
}

Předložená studie popisuje numerickou simulaci saltačního pohybu kulovité částice v korytě s prríčně skloněným drsným dnem. Modelování saltačního pohybu částice $\mathrm{v}$ korytě $\mathrm{s}$ př́ičně skloněným dnem je důležité pro pochopení např. morfologie a topografie říčního dna, eroze břehů nebo trrídění sedimentujících částic podle jejich velikosti při pohybu sedimentů v tocích. Vztahy popisující 2D nebo 3D saltační pohyb rotující kulovité částice jsou známy jen pro obdélníkové koryto. Proto byla věnována pozornost modelování saltačního pohybu rotující kulovité částice $v$ korytě $s$ príčně skloněným dnem za následujících předpokladů: kulovitá částice (průměr $d_{p}$, hustota $\rho_{p}$ ) se pohybuje translačně a současně rotuje kolem svého těžiště $v$ korytě $s$ príičně i podélně skloněným dnem $\mathrm{v}$ kapalině o hustotě $\rho$ a dynamické viskositě $\mu$.

Systém rídících rovnic je dán rov. (2)-(4). Proudění kapaliny je ustálené a rovnoměrné, rychlostní profil je popsán logaritmickým zákonem (rov. (5)). Účinek turbulentních fluktuací je možno zanedbat. Koncentrace unášených částic je nízká a lze proto zanedbat jejich vzájemné kolize i vliv částic na proud kapaliny a pohyb všech částic může být reprezentován pohybem jednotlivé částice.

Pro modelování jsou uvažovány účinky odporové síly (rov. (6)), síly přídavné hmoty, gravitační síly ponořené částice, Bassetovy síly, Magnusovy síly (rov. (9)-(12)) a odporového momentu (rov. (14)), působících na částici. Předložený numerický model je založen na autory vyvinutém 3D modelu saltačního pohybu kulovité částice, který počitá s translačním i rotačním pohybem částice.

Dno koryta tvoří rovina proložená vrcholky nerovností dna, dno je skloněno prríčně pod úhlem $\theta_{l}$ a podélně pod úhlem $\theta_{s}$. Systém souřadnic $O x z$ spojený s rovinou dna koryta je výsledkem dvojité transformace (rotace o $\theta_{s}$ kolem osy $O z$ "' a rotace o úhel $\theta_{l}$ kolem osy $O x^{\prime}$ ), obr. 1 . Pohyb částice je závislý na dvou bezrozměrných parametrech - na Reynoldsovu číslu Re a na rotačním Reynoldsovu číslu $\operatorname{Re}_{\omega}$. Pro odvození vzájemného vlivu translačního i rotačního pohybu částice jak na součinitel odporu částice $C_{D}$, tak na součinitel odporového momentu částice $C_{\omega}$ byl využit 3D numerický model pro translační pohyb rotující částice, odvozený autory.

Pro výpočet trajektorie částice a její závislosti na př́čném sklonu dna koryta, průměru částice a smykové rychlosti nosné kapaliny byla použita stochastická metoda a koncept kontaktní zóny. Vlivem př́ičného sklonu dna koryta dochází k odchylce trajektorie částice od směru proudu. Účinek příčného sklonu dna koryta se projeví zejména odchylkou trajektorie částice od směru proudu ve směru shodném s prričným sklonem dna kory- ta. Byly vypočteny trajektorie částic začínajících svůj pohyb $\mathrm{v}$ jednom bodě a bylo ukázáno, že trajektorie jsou náhodného charakteru a tvoří společně svazek trajektorií. Byly definovány počátek, osa a hranice svazku. Na základě uskutečněných simulací bylo zjištěno, že osa svazku a hranice svazku mohou být pro nízké a střední hodnoty př́čného sklonu dna koryta aproximovány př́mkami (obr. 2). Deviační úhel $\alpha_{p}$ osy svazku od směru proudu je téměr̆ lineárně závislý na př́ičném sklonu dna koryta $\theta_{l}$ pro hodnoty $\theta_{l}$ do $20^{\circ}$. Deviační úhel $\alpha_{p}$ roste $\mathrm{s}$ př́čným sklonem dna koryta $\theta_{l}$ nebo průměrem částice $d_{p}$, klesá s rostoucí třecí rychlostí kapaliny $u_{*}$ (obr. 3 ).

Závislost deviačního úhlu $\alpha_{p}$ na průměru částice $d_{p}$ je znázorněna na obr. 4 pro zvolený př́čný sklon $\theta_{l}=20^{\circ} \mathrm{a}$ drsnost dna koryta $k_{s}=1 \mathrm{~mm}$ jako monotónně stoupající funkce. Proto vlivem prríčného sklonu dna koryta může dojít $\mathrm{v}$ průběhu saltačního pohybu částic $\mathrm{v}$ korytě $\mathrm{k}$ jejich roztř́idění podle jejich velikosti. Bylo spočteno několik prríkladů třídění, definováno kriterium třídění a určeny oblasti třídění podle velikosti částic a sklonu dna koryta (obr. 5).

\section{Seznam symboli}

$C_{D} \quad-$ odporový koeficient částice [-],

$C_{D 0} \quad-$ odporový koeficient částice pohybující se translačně bez rotace, $\omega_{R}=0[-]$,

$C_{m} \quad-$ koeficient síly prídavné hmoty [-],

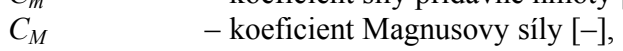

$C_{\omega}-$ momentový koeficient odporu rotující částice pohybující se translačně [-],

$C_{\omega 0}-$ momentový koeficient odporu částice rotující $\mathrm{v}$ klidné kapalině, $v_{R}=0[-]$,

$d_{p} \quad-$ průměr pohybující se částice $[\mathrm{m}]$,

$\boldsymbol{F}_{B} \quad-$ Bassetova síla na jednotku objemu částice [N $\left.\mathrm{m}^{-3}\right]$,

$\boldsymbol{F}_{D} \quad-$ odporová síla na jednotku objemu částice [N $\mathrm{m}^{-3}$ ],

$\boldsymbol{F}_{\mathrm{g}}-$ gravitační síla ponořené částice na jednotku objemu částice $\left[\mathrm{N} \mathrm{m}^{-3}\right]$,

$\boldsymbol{F}_{m} \quad-$ síla prídavné hmoty na jednotku objemu částice $\left[\mathrm{N} \mathrm{m}^{-3}\right]$,

$\boldsymbol{F}_{M} \quad-$ Magnusova síla na jednotku objemu částice $\left[\mathrm{N} \mathrm{m}^{-3}\right]$,

g - gravitační zrychlení $\left[\mathrm{m} \mathrm{s}^{-2}\right]$,

$J \quad-$ moment setrvačnosti částice $\left[\mathrm{kg} \mathrm{m}^{2}\right]$,

$K \quad-$ Karmanova konstanta $[-]$,

$k_{s} \quad-$ drsnost dna [m],

M - moment vazkých sil působící na rotující částici v kapalině $[\mathrm{N} \mathrm{m}]$,

$r_{p} \quad-$ poloměr pohybující se částice [m],

$\mathrm{Re}_{\omega} \quad-$ Reynoldsovo číslo při rotačním pohybu [-],

$r_{p} \quad-$ poloměr pohybující se částice [m],

$\boldsymbol{r}_{O p}\left(x_{p}, y_{p}, z_{p}\right)$ - radius-vektor těžiště částice [m],

$\operatorname{Re}-$ Reynoldsovo číslo při translačním pohybu částice [-],

$\operatorname{Re}_{\omega} \quad-$ Reynoldsovo číslo při rotačním pohybu částice [-],

$t \quad-$ čas [s],

$u_{*} \quad-$ smyková rychlost $\left[\mathrm{m} \mathrm{s}^{-1}\right]$

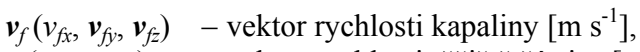

$\boldsymbol{v}\left(v_{x}, v_{y}, v_{z}\right) \quad$ - vektor rychlosti těžiště částice $\left[\mathrm{m} \mathrm{s}^{-1}\right]$, 


\begin{tabular}{|c|c|c|c|}
\hline$v_{R}$ & - vektor relativní rychlosti částice $\left[\mathrm{m} \mathrm{s}^{-1}\right]$, & $\mu$ & - součinitel dynamické viskozity [Pa s], \\
\hline $\mathrm{y}_{0}$ & $\begin{array}{l}\text { - svislá souradnice místa nulové rychlosti } \\
\text { kapaliny }[\mathrm{m}]\end{array}$ & $\begin{array}{l}\theta_{l} \\
\theta_{s}\end{array}$ & $\begin{array}{l}\text { - úhel prríčného sklonu dna koryta [stupně], } \\
\text { - úhel podélného sklonu dna koryta [stupně], }\end{array}$ \\
\hline$t_{p}$ & $\begin{array}{l}\text { - deviační úhel, tj. úhel mezi osou svazku } \\
\text { trajektorií částic a směrem proudu [stupně], }\end{array}$ & & $\begin{array}{l}\text { - hustota kapaliny }\left[\mathrm{kg} \mathrm{m}^{-3}\right] \\
\text { - hustota částice }\left[\mathrm{kg} \mathrm{m}^{-3}\right]\end{array}$ \\
\hline$\alpha_{p}$ & $\begin{array}{l}\text { - disperzní úhel - úhel mezi projekcí hranice a } \\
\text { osy svazku na rovinu dna [stupně], }\end{array}$ & $\begin{array}{l}\boldsymbol{\omega}\left(\omega_{x}, \omega_{y}, \omega_{z}\right) \\
\boldsymbol{\omega}_{R}\end{array}$ & $\begin{array}{l}\text { - vektor úhlové rychlosti rotující částice }\left[\mathrm{s}^{-1}\right] \text {, } \\
\text { - relativní úhlová rychlost částice }\left[\mathrm{s}^{-1}\right] \text {. }\end{array}$ \\
\hline
\end{tabular}

